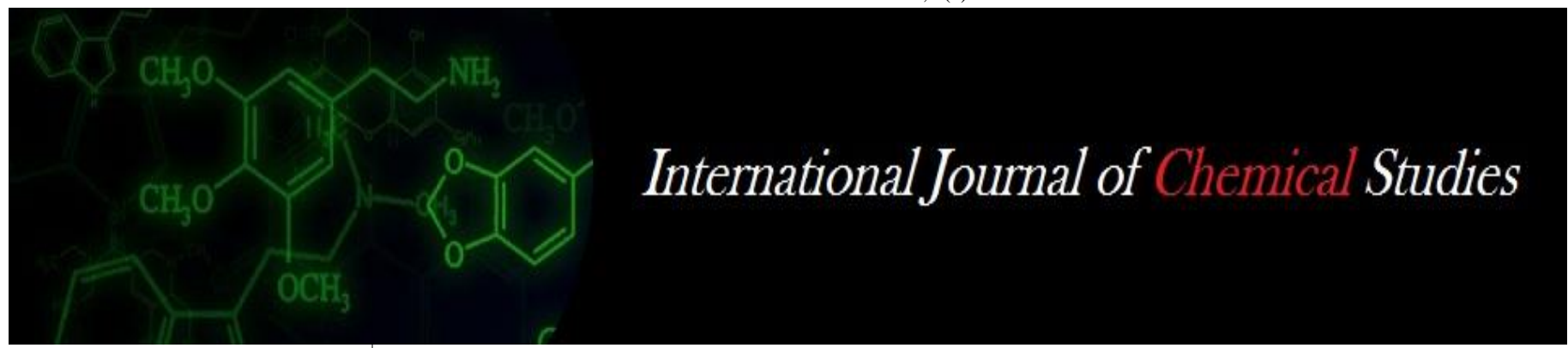

P-ISSN: 2349-8528

E-ISSN: 2321-4902

www.chemijournal.com

IJCS 2021; 9(1): 189-192

(C) 2021 IJCS

Received: $30-10-2020$

Accepted: 03-12-2020

Shivam Suthar

M.Sc. Research Scholar, School

of Agriculture, Lovely

Professional University, Punjab,

India

Sarvjeet Kukreja

Assistant Professor, Lovely

Professional University, School

of Agriculture, Lovely

Professional University, Punjab,

India
Corresponding Author:

Shivam Suthar

M.Sc. Research Scholar, School

of Agriculture, Lovely

Professional University, Punjab,

India

\section{Effect of different levels of sulphur on growth and yield of fenugreek crop: A review}

\author{
Shivam Suthar and Sarvjeet Kukreja
}

DOI: https://doi.org/10.22271/chemi.2021.v9.i1c.11231

\begin{abstract}
The effective use of sulphur doses, yield of fenugreek crop are significantly higher as compared with control during first and second years of experimentation. On the basis of economics, application of sulphur/ha is significantly better for achieving higher gross income and benefit cost ratio of fenugreek as well as economically more net return. This study aims at reviewing the effect of different level of sulphur on growth and yield of fenugreek. Sulphur showed a synergistic effect on yields of fenugreek. Protein content increases significantly with increase of sulphur. Information gained from this study can be utilized to develop more efficient sulphur fertilization levels in winter fenugreek. Sulphur up to $50 \mathrm{~kg}$ S/ha fundamentally expanded the yield-ascribing characters; the seed and natural yield; and the net returns of fenugreek.
\end{abstract}

Keywords: Sulphur, fenugreek, growth, yield

\section{Introduction}

Fenugreek is considered as flavor just as vegetable yield and is a significant vegetable and sauce crop filled in Northern India during Rabi season for leaves, shoot and seed. India, appropriately known as place where there is flavor is the biggest maker, buyer and exporter of flavors on the planet. Its new delicate leaves are likewise taken as vegetable which are wealthy in iron, calcium, nutrients and fundamental amino acids, similar to lysine, leucine also, phenylalanine. Fenugreek (Trigonella foenum-graecum L.), has a place with subfamily Papilionaceae of the Leguminous family, is an erect yearly herbaceous plant that grows up to $10-50 \mathrm{~cm}$ stature. This species is indigenous to western Asia and southeastern Europe (Sulieman et al., 2008). Due to palatable and restorative estimations of its seeds, it has for some time been generally developed in Asia, Africa and Mediterranean nations for a long time (Amin et al., 2005). These days, the quantity of the plants utilized for clinical design is about 35.000 species. The vast greater part $(80 \%)$ of the total populace utilizes the plants in treatment. One fourth of the advanced pharmacopeias is unadulterated substances that overlooked from plants (Anonymous, 2010). The majority of the plants utilized for this point have been gathered from nature and creation of them is restricted, shockingly. Fenugreek (Trigonella foenum-graecum L.) has a long history of restorative uses in Ayurveda. It is notable as conventional medication for diabetes, acid reflux, rise of lipids and edema (liquid maintenance) of the legs. Fenugreek is additionally great wellspring of dietary protein for human and creatures. Its seeds have a solid fragrance and to some degree harsh in taste. Seeds of fenugreek are utilized locally as yellow color in beautifiers and therapeutic purposes. Fenugreek is a decent soil renovator and is broadly utilized as a green fertilizer (Abdelgani et al., 1999). Fenugreek is utilized as a flavor, vegetable and a restorative plant. Since cancer prevention agent properties have been connected to medical advantages of common items, such properties were concentrated in developed fenugreek seeds which are viewed as more advantageous than dried seeds (Dixit et al., 2005). Fenugreek has a high extent of protein (roughly 20-30\%) just as amino corrosive, 4-hydroxyisoleucine, which has high potential for insulin stimulating action. Sulphur assumes an essential function in plant digestion. Sulphur establishes the principle component of amino acids, for example, cysteine and methionine, which are of basic supplement esteem. Sulphur is likewise liable for union of specific nutrients (biotin and thiamine), proteins, fats and digestion of sugars. It has likewise been accounted for to advance nodulation in vegetables coming about in to higher creation (Tondon, 1991). 
The current investigation was, for such thought processes, attempted with the goal to discover and decide the impact of vermicompost and sulphur on development ascribes, root knobs, leghaemoglobin substance, seeds and straw yields, net returns and supplement take-up of Sulphur is one of the significant plant supplements for expanding yield of the harvest. Sulphur assumes a crucial function in plant digestion. It establishes the fundamental component of amino acids, for example, cysteine and methionine, which are of fundamental supplements. Sulphur affects the root development in plants (Kacar, 1984). Lal et al. (2015) announced that application 30 $\mathrm{kg} \mathrm{S}$ ha-1 delivered the most noteworthy number of essential branches plant-1 and number of cases plant-1 with greatest seed yield of fenugreek. Gordara et al. (2013) got the most noteworthy seed yield of fenugreek from the use of $45 \mathrm{~kg} \mathrm{~S}$ ha-1 which was factually like $30 \mathrm{~kg} \mathrm{~S}$ ha-1; while Nehara et al. (2006) ${ }^{[10]}$ got the most elevated seed yield from $25 \mathrm{~kg} \mathrm{~S}$ ha-1. Thusly, obviously seed yield of fenugreek can be expanded by wise use of phosphorous and sulphur treatment. In any case, the data on fenugreek research with respect to phosphorous and sulphur preparation isn't accessible in Bangladesh fenugreek.

\section{The function of sulphur}

The scope of organic mixes that contain sulphur is immense. $\mathrm{S}$ is found in nutrients viz, biotin and thiamine; cofactors Sadenosyl-L-methionine, coenzyme A, molybdenum cofactor (MoCo), and lipoic corrosive; the chloroplast lipid sufloquinovosyl 524 diacylglycerol; and numerous auxiliary mixes (Leustek, 2002, Leustek and Saito, 1999). It likewise serves significant auxiliary, administrative and synergist capacities with regards to protein, and as a significant cell redox cradle as the tripeptide glutathione and certain proteins, for example, thioredoxin, glutaredoxin and protein disulfide isomerase. A component of numerous sulphur-containing mixes is that the $\mathrm{S}$ moiety is regularly legitimately associated with the synergist or synthetic sensitivity of the compound. A brilliant model is the manner by which cysteine deposits in proteins now and again structure covalent disulfide bonds. Disulfides can, thusly, be diminished to the thiol structure by glutathione or redox proteins like thioredoxin (Leustek and Saito, 1999; Saito, 2000). For certain catalysts, disulfide bond arrangement serves to control action. Numerous catalysts of carbon dioxide obsession are directed in this manner as a way to facilitate their movement with the light responses of photosynthesis. The administrative particle for this situation is thioredoxin, which lessens target catalysts utilizing electrons from ferredoxin (Leustek and Saito, 1999; Saito, 2000; Scherer, 2001; Matsubayashi et al., 2002).

\section{Sulphur deficiencies in soil}

$\mathrm{S}$ inadequacy in crops has as of late become far and wide (Scherer, 2001). Beforehand, adequate $S$ to meet yield prerequisites was acquired from the continuous accidental increases of $\mathrm{S}$ to soil when $\mathrm{N}$ and $\mathrm{P}$ composts, for example, ammonium sulfate and single superphosphate, were applied. Modern contamination because of coal burning moreover contributed considerable measures of $\mathrm{S}$ for plant needs by elevated affidavit. In the course of the most recent twenty years, notwithstanding, there has been a central move in the $S$ balance toward deficiency in horticultural frameworks for a few reasons. High investigation $\mathrm{N}$ and $\mathrm{P}$ composts have continuously supplanted customary ones that contain S. Likewise, yields of agrarian harvests have expanded especially, and at times dramatically increased, during the last twenty years, bringing about expanded expulsion of supplements, counting S from soils (Scherer, 2001). In serious yield revolutions including oil crops, $S$ take-up can be extremely high, particularly when the yield buildup is taken out from the field alongside the item. This prompts extensive $S$ exhaustion in soil if the relating measure of $S$ isn't applied through compost. It is presently entrenched that $S$ inadequacy is wide spread in Indian soils, and no doubt is on the expansion. $\mathrm{S}$ inadequacy which was seen numerous years prior just in restricted regions has inundated a lot bigger territory in its overlap (Takkar, 1987).

\section{Sulphur fertilizers}

Creature excrements are an amazing wellspring of sulphur and are even as for nitrogen. Harvest deposits, for example, feed and straw are additionally acceptable. Among the inorganic manures, sulfate of potash magnesia is a characteristic compost, langbeinite. Gypsum is calcium sulfate.

Unadulterated sulphur for rural intentions is acquired from normally happening stores in the southern U.S. or on the other hand as a side-effect of the desulfurization of different gases and coal. It very well may be bought either as a fine residue, frequently called blossoms of sulphur, or granulated sulphur. Sulphur dust is a blast danger, so it bought to be maneuvered carefully; the granulated structure is more secure to utilize. Epsom salts are magnesium sulfate, either solidified from common stores or incorporated. Potassium sulfate and ammonium sulfate are combined items. Sulphur is once in a while insufficient in the dirt inasmuch as some sulphurcontaining materials are spread. Inadequacies happen when the utilization of concentrated, sans sulphur manures animate plant development and cause the evacuation of soil sulphur without remuneration.

Gypsum applied to a soluble soil will frequently improve the dirt structure by dissolving sodium carbonate when the dirt is wet. Gypsum additionally improves plant development in a corrosive soil. The explanation is not clear, however some corrosive soils are exceptionally drained and perhaps low in sulphur. Unadulterated sulphur is utilized to ferment an antacid soil. Sulphur-adoring microbes oxidize it, so, all in all it joins with water to shape sulfuric corrosive. Sulphur is now and again applied to make phosphorus more accessible in soluble soils, maybe what could be compared to superphosphate.

\section{Effect of sulphur in production:}

The yield expanded with due to improvement in development characters and yield credits. The impact of Sulphur in improving the harvest yield may be expected to low accessibility of its protein content. Comparative impact of manure application was likewise gotten in the event of straw yield which was because of great impact of sulphur, manure on development characters of Lentil. Gather record expanded with expanding sulphur levels when contrasted with control. This may be because of the way that better movement of photosynthesis from source to sinc expands the seed yield. The discoveries are right up front similarity with these Singh et al. (2004) Singh and Chauhan (2005) and Singh and Sekhan (2007).

The number of grain per plant, grain weight per plant, and yield was found maximum in case of $\mathrm{ssp}+$ granular sulphur. 


\section{Importance of sulphur in fenugreek}

The substance of protein, tryptophan, lysine, methionine, globulin and egg whites expanded fundamentally with expanding levels of Sulphur up to $30 \mathrm{~kg} / \mathrm{ha}$. The expanding pattern in the protein divisions might be ascribed to the way that Sulphur animates the biosynthesis of proteins and Sulphur containing amino acids which is reflected during the measure of the examples. Comparable pattern was noticed for tryptophan and lysine too. Sulphur being a basic part of amino acids, co-catalysts engaged with protein blend may have prompted the expanding pattern in protein and amino acids obvious in the current examination. Comparable discoveries have been accounted for by Mishra et al., (2012), Raikwar et al., (2012) in wheat and grain individually. Jamal et al., (2005) detailed tantamount outcomes in soybean and Chiaiese et al., (2004) in chickpea. Egg whites content likewise expanded essentially with expanding levels of Sulphur up to $30 \mathrm{Kg} / \mathrm{Ha}$. This might be because of high amino corrosive content especially Sulphur containing amino corrosive methionine which is a significant constituent of egg whites protein division. On the opposite globulin division didn't show any increment. The outcomes are in understanding to the discoveries of Sharma and Sharma (2014); Sharma et al., (2013).

\section{Effect of sulphur on various parameters of fenugreek}

The sulphur applications by methods for plant tallness estimations of fenugreek in $2007(P<0.01)$ and long term's normal $(P<0.05)$. Be that as it may, the impact of sulphur application was not huge in 2006. The most elevated plant tallness (40.8-40.0 cm) was gotten from $40 \mathrm{~kg} \mathrm{~S}$ ha-1 application in the two years. The least plant tallness esteem $(40.3-38.3 \mathrm{~cm})$ was gotten in $20 \mathrm{~kg} \mathrm{~S}$ ha-1 application. Plant statures were expanded by expanding sulphur dosages. In the past investigations identified with sulphur application in fenugreek, Jat and Shaktawat (2001) also, Nehara et al. (2006) ${ }^{[10]}$ detailed that the most elevated plant tallness was gotten from $100 \mathrm{~kg}$ ha-1 and $50 \mathrm{~kg}$ ha-1 $\mathrm{S}$ applications, individually.

The impact of various sulfur levels on the quantity of parts of fenugreek was not huge in the trial a long time. As the qualities changed somewhere in the range of 2.6 and 2.7 branch plant- 1 for first year, the all sulphur applications gave 2.6 branch plant-1 for second year. Aside from our results, Jat and Shaktawat (2001) and Nehara et al. (2006) ${ }^{[10]}$ expressed that there was connection between the sulphur applications. They got the most noteworthy number of branches with expanding sulphur levels up to $100 \mathrm{~kg}$ ha- 1 and $50 \mathrm{~kg}$ ha

\section{Fenugreek response to sulphur nutrition}

The sulphur portions on the principal unit tallness of fenugreek in 2006 and in normal of the years; however no critical contrasts were found in 2007 (Table 1). As the most elevated first unit tallness $(17.8 \mathrm{~cm})$ was recorded in $40 \mathrm{~kg} \mathrm{~S}$ ha-1 application in 2006, first case statures of 17.2 and 17.3 were gotten from S0 and S20 applications, separately (Table 2). The main case tallness expanded with expanding sulphur levels. Comparative outcomes were acquired by Jat and Shaktawat (2001) and Nehara et al. (2006) ${ }^{[10]}$ who detailed that general yield attributes of fenugreek expanded with expanding sulphur levels.

The impact of various sulphur levels on the quantity of seeds in unit of fenugreek was not critical in 2006, while huge contrasts were found in $2007(P<0.05)$ and in normal of the years $(P<0.01)$. The most noteworthy qualities were gotten
(13.9-13.5 seed case 1) from $20 \mathrm{~kg}$ ha- $1 \mathrm{~S}$ applied plots in the two years, and the least qualities (13.6-12.8 seeds unit 1) were acquired from the control plots, individually. Aside from our discoveries, Nehara et al. (2006) ${ }^{[10]}$ revealed that the yieldcrediting characters expanded fundamentally with increment of sulphur levels. As far as the quantity of seeds in unit, $\mathrm{N} x \mathrm{~S}$ association was not huge in the two years of the examination, while there were huge $(P<0.05)$ contrasts in the normal of year

\section{Effect of sources of sulphur in fenugreek}

Distinctive sulphur applications had critical $(P<0.05)$ impacts on the case length of fenugreek in 2006. In any case, these applications were not critical in 2007 and in normal of the years. As to this boundary the most noteworthy worth $(12.7$ $\mathrm{cm})$ was gotten from $40 \mathrm{~kg}$ ha-1 sulphur portion in 2006, though the most noteworthy worth $(12.3 \mathrm{~cm})$ was acquired from the control plots in 2007. While control plots gave the most minimal worth $(12.2 \mathrm{~cm})$ in the main year, $40 \mathrm{~kg} \mathrm{~S}$ ha-1 application gave the least worth $(11.9 \mathrm{~cm})$ in the subsequent year. Our outcomes are in co thousand-seed weight was fundamentally $(P<0.05)$ influenced by sulphur preparation in the principal test year. However, it was not influenced signicantly in the second trial year and in the normal of the years. As the most elevated worth $(18.8 \mathrm{~g})$ was gotten from 40 $\mathrm{kg} \mathrm{S}$ ha-1 application in 2006, $20 \mathrm{~kg}$ ha-1 sulphur application gave $18.2 \mathrm{~g}$ thousand-seed weight in 2007. The most reduced qualities (18.2-17.9 g) were acquired from $20 \mathrm{~kg} \mathrm{~S}$ ha-1 and $40 \mathrm{~kg} \mathrm{~S}$ ha-1 applications in 2006 and 2007, individually. Nehara et al. (2006) ${ }^{[10]}$ expressed that the yield-ascribing characters of fenugreek were essentially expanded up to $50 \mathrm{~kg}$ S/ha applications. ncurrence with the after effects of Nehara $e t$ al. (2006) ${ }^{[10]}$

The impact of expanding sulphur dosages on the seed protein substance of fenugreek was huge $(P<0.05)$ in 2006 and in the normal of the years, however the second year there were no huge contrast. As per the two years midpoints the most noteworthy qualities (23.5-23.3\%) were acquired from $40 \mathrm{~kg}$ ha-1 sulphur application. Control plots gave the most minimal qualities (23.1-23.0\%).

Singh and Meena (2004) thought that general improvement in development characters of plant inferable from sulphur application might be because of sulphur upgraded cell duplication, extension and development bringing about more noteworthy measures of dry issue in contrast with sulphur lacking plant. Comparative discoveries of expanded plant development and improvement with sulphur application were likewise noted by Jat et al. (2012).

Ali et al. (2012) supported the effective utilization of Rhizobial immunization for fenugreek and asserted a productive improvement in its selection to bone-dry and semiarid soils, yet shockingly no further exploration was made for rhizobial vaccinations. In additions, in the most recent decade fenugreek was examined for hefty metal poisonousness (Sinha et al., 2007; Elleuch et al., 2013), planting date (Nandre et al., 2011), intercropping (Shirzadi et al., 2011), phosphorous manure dosages (Khan et al., 2005; Jat et al., 2012), grub bank (Solorio-Sa'nchezSa'nchez et al., 2014) and reaction to exogenous utilization of plant development controllers (Danesh Talab et al., 2014). All the more as of late, Pouryousef et al. (2015)

\section{Conclusion}

Fenugreek is utilized as flavors for planning of different dishes just as to fix numerous sicknesses. Trigonella foeneum 
graecum set up itself as a restorative plant because of its various exercises, for example, anticancer, calming, clean, Spanish fly, astringent, harsh, demulcent, emollient, expectorant, anthelmintic, injury recuperating and gastro defensive. Not just that it is one of the essential enhancements utilized for type II diabetics or noninsulin-subordinate diabetes mellitus (NIDDM). Fenugreek isn't just a rich wellspring of polysaccharide galactomannan yet in addition it is the wellspring of saponins, for example, diosgenin, yamogenin, gitogenin, tigogenin, and neo tigogenin. It additionally contains flavonoids, amino corrosive, alkaloids and other bioactive constituents like adhesive, unpredictable oils and so forth Not just important exercises, it has some results too as it might build the danger of dying, may diminish the potassium levels in the blood, deadness, facial growing, breathing issue and blacking out like a reason for an unfavorably susceptible response, and furthermore discombobulation, loose bowels and gastric issues. The utilization of Fenugreek has been demonstrated safe for human life and might be effectively executed for medical advantage, through its rich fiber content and other bioactive parts. Fenugreek seed encourages not exclusively to decrease the low thickness cholesterol and triacylglycerol yet in addition used to lessen glucose level with its high centralization of phytochemicals.

\section{Reference}

1. Aishwath OP, Khurana HS, Anwer MM. A review on the effect of integrated nutrient management on yield and quality of major seed spice crops in India. Better Crops South Asia 2011,19-21. 2.

2. Bochalia GS. Response of fenugreek (Trigonella foenumgraecum L.) and type to crop geometry, agro-chemicals and sulphur fertilization. Ph.D. Thesis, MPUAT, Udaipur 2008.

3. Altuntas E, Ozgoz E, Taser OF. "Some physical properties of fenugreek (Trigonella foenumgraecum L.) Seed", Jr. Food Eng 2005;(71):37-43.

4. Betty R. "The Many Healing Virtues of Fenugreek", Spice India 2008,17-19p.

5. Bhati DS. "Effect of irrigation and phosphorus on seed yield and its attributes of fenugreek (Trigonella foenumgraecum L.)", Indian Jr. Agron 1993;38(3):449-452.

6. Birjees BS, Bhanger ML, Memon SH. "Antioxidative activity of extracts from fenugreek seeds (Trigonella foenum-graecum L.)", Pakistan Jr. Ann. Environ. Chem 2008;9:78-83.

7. Chaudhary GR. "Response of fenugreek (Trigonella foenum-graecum L.) to N, P and Rhizobium inoculation", Indian Journal of Agronomy 1999;44(2):424-426

8. Dayanand. Effect of phosphorus and sulphur on growth and yield of fenugreek (Trigonella foenum-graecum L.) M.Sc.(Ag.) Thesis Rajasthan Agriculture University, Bikaner, Rajasthan 1996.

9. Jat ML, Sharma OP, Shivran DR, Jat AS, Baldav Ram. Effect of phosphorus, sulphur and growth regulator on yield attributes, yield and nutrient uptake of fenugreek. Ann. Agric. Res 1998;19(1):89-91.

10. Nehara KC, Kumawat PD, Singh BP. Response of fenugreek (Trigonella foenum-graecum L.) to phosphorus, sulphur and plant growth regulators under semi-arid eastern plains zone of Rajasthan. Indian Journal of Agronomy 2006;51(1):73-76.

11. Rathore PS, Manohar SS. Effect of date of sowing, nitrogen and phosphorus on quality and nodulation of fenugreek. Indian Cocoa, Arecanut and Species Journal 1990;13(4):148-152. 